\title{
Fine-scale genetic structure in Pinus clausa (Pinaceae) populations: effects of disturbance history
}

\author{
KATHLEEN C. PARKER* $\uparrow$, J. L. HAMRICK $\uparrow$, ALBERT J. PARKER $\uparrow \&$ JOHN D. NASON \\ $\dagger$ Department of Geography, University of Georgia, Athens, GA 30602, $¥$ Departments of Botany and Genetics, \\ University of Georgia, Athens, GA 30602 and §Department of Botany, lowa State University, Ames, IA 50011, U.S.A.
}

\begin{abstract}
Spatial autocorrelation analyses of 12 allozyme loci were used to compare genetic structure within populations of two varieties of Pinus clausa. P. clausa var. immuginata populations tend to be unevenaged, with continuous recruitment in small gaps created by wind damage, whereas P. clausa var. clausa populations are more even-aged, with recruitment postdating periodic canopy fires. Three var. immuginata populations and three matched pairs of var. clausa populations, including both a mature and a nearby recently burned population, were examined. Aggregation of multilocus genotypes at small distances was evident in all young var. clausa populations. Little inbreeding was apparent among juveniles or adults in these populations; their genetic structure is likely to have resulted from limited seed dispersal. Genotypes were not significantly spatially structured in nearby matched mature populations. Genetic structure was less evident in var. immuginata populations. Aggregated genotypes were only apparent in the population where patches included juveniles of similar ages; dense juvenile clumps in the other two var. immuginata populations comprised a variety of ages. Interannual variability in allele frequencies of surviving seedlings may account for the absence of genetic structure in these populations.
\end{abstract}

Keywords: disturbance history, gene dispersal, genetic structure, Pinus clausa, spatial autocorrelation.

\section{Introduction}

Fine-scale genetic structure is evident within populations when the distribution of genetic variation among individuals grouped at increasing spatial scales is nonrandom (McCauley, 1997). A number of evolutionary and ecological processes affect the development of genetic structure within plant populations, including pollen and seed dispersal (Wright, 1943; Latta et al., 1998), microhabitat variation in selection (Linhart et al., 1981; Epperson \& Allard, 1989; Slatkin \& Arter, 1991), adult population density (Hamrick \& Nason, 1996), spatial and temporal patterns of seedling establishment (Ellstrand, 1992; Schnabel \& Hamrick, 1995; Hamrick \& Nason, 1996), and stand age and history (Knowles et al., 1992; Hamrick et al., 1993; Schnabel et al., 1998). Probably the most widely examined influence on finescale genetic structure has been gene movement, including both pollen and seed dispersal. Extensive gene movement theoretically offsets the influence of micro-

*Correspondence. E-mail: kcparker@arches.uga.edu habitat selection, which may foster fine-scale genetic differentiation within populations. With wind-pollinated and wind-dispersed species, however, gene dispersal generally decreases with increasing interplant distance; and spatial structure may result from genetic drift associated with limited gene flow over greater distances (Wright, 1943; Heywood, 1991). These neighbourhoods may become ecologically adapted to their microhabitat through selection, reinforcing genetic structure (Berg \& Hamrick, 1995). Although various temperate tree species have been studied to determine whether genetic structure is evident within populations of wind-pollinated and -dispersed species, most have found either no detectable pattern (e.g. Pinus contorta: Epperson \& Allard, 1989; P. banksiana: Xie \& Knowles, 1991) or only weak genetic structure, typically at small interplant distances (e.g. Acer saccharum: Perry \& Knowles, 1991; Picea abies: Leonardi et al., 1996; Quercus laevis: Berg \& Hamrick, 1995; Fagus sylvatica: Leonardi \& Menozzi, 1996).

Other factors that affect fine-scale genetic structure have been examined less thoroughly than gene movement. Boyle et al. (1990) and Knowles et al. (1992) 
found differences in the development of genetic structure within populations of Larix laricina and Picea mariana, respectively, which they attributed to differences in stand history. Sites that were colonized from a homogeneous outside seed source that included few seed trees showed little evidence of genetic structure, whereas colonization of a large disturbed site by seeds from many founder trees (Knowles et al., 1992) or continuous recruitment through gap-phase dynamics (Boyle et al., 1990) led to more genetic structure within the populations studied. Boyle et al. (1990) were reluctant to generalize about the effects of disturbance on genetic structure, however, noting that the distribution of genetic variation within a repopulated site after disturbance reflects various factors, including size of the area disturbed, extent of mortality, proximity of potential seed trees, seed production at the time of disturbance, and climatic conditions following seed dispersal.

This study examines the effect of disturbance history on the development of genetic structure in two varieties of Pinus clausa (Chapm. ex Engelm.) Vasey ex Sarg. (sand pine) in Florida. P. clausa is ideal for such analyses because the two varieties differ in their prevalent disturbance regimes. P. clausa var. clausa (Ocala sand pine) bears serotinous cones throughout most of its range in the Florida peninsula; populations are often strongly even-aged, with the dominant age reflecting the time since the last stand-destroying fire (Myers, 1990; Parker et al., 2001). In most locations within its range in the Florida panhandle, P. clausa var. immuginata D.B. Ward (Choctawhatchee sand pine) has open cones. Stands are more uneven-aged, with recruitment occurring continuously in small gaps in the forest that are opened by small-scale disturbances, such as wind damage associated with hurricanes (Parker et al., 2001). Specific questions addressed include: (i) Within each of nine Pinus clausa populations, do closely spaced individuals show more relatedness in terms of their allozyme genotypes than more distantly spaced individuals?; (ii) Do different age groups within each population show different patterns of fine-scale genetic structure and inbreeding?; (iii) Are differences among populations in spatial genetic structure related to adult or seedling density differences?; and (iv) Do the two varieties of $P$. clausa differ in the strength of genetic structure that has developed within populations and, if so, can these contrasts be related to differences in disturbance history? The initial hypothesis was that populations of var. clausa would typically regenerate in a narrow window of time after disturbance from a relatively homogeneous seed supply; in contrast, var. immuginata would experience continuous recruitment in small gaps over time, with seeds coming primarily from adults adjacent to the gaps. The intervarietal difference in both the spatial and temporal dispersal of seeds would hypothetically cause var. immuginata populations to show more fine-scale genetic structure than var. clausa populations.

\section{Methods}

\section{Species biology and study sites}

Pinus clausa is virtually endemic to Florida, where it inhabits xeric, low-nutrient Quaternary and modern dunes and beach ridges along the coast and in the central part of the peninsula (Fig. 1). It is the canopy dominant of the scrub ecosystem that occurs on these sites (Myers, 1990). The initial differentiation between the two varieties was based on their disjunct distribution and purported differences in cone serotiny. Natural populations of $P$. clausa var. clausa are restricted to the peninsula, where the majority of individuals bear serotinous cones (Little \& Dorman, 1952). The importance of stand-initiating canopy fires occurring every 30-60 years is well established in var. clausa (Myers, 1990), and most mature peninsula populations are unimodal in their age distributions, dating either from the last intense fire or, in some cases, agricultural abandonment (Parker et al., 2001). Regeneration is rare in these older populations in the absence of canopy fire (Parker et al., 1997a). In contrast, P. clausa var. immuginata occurs on the Florida panhandle and typically bears open cones. Although spot fires and occasional stand-initiating fires occur in this variety, disturbances are typically smaller in scale and are associated with hurricanes and extra-tropical cyclones more often than with fire (Parker et al., 2001). Recruitment is ongoing in these populations; consequently most var. immuginata populations are uneven-aged (Cooper et al., 1959; Parker et al., 2001), with regeneration occurring in gaps created by frequent localized wind damage.

Since the original description of the two varieties of Pinus clausa, genetic analyses and common garden, or provenance, studies have revealed other contrasts between the two varieties. Var. clausa consistently produces seeds on an annual basis, whereas var. immuginata masts on a 4-6-year cycle (Outcalt \& Balmer, 1983). Seeds are larger in var. clausa $\left(0.00961 \mathrm{~g} \mathrm{seed}^{-1}\right)$ than in var. immuginata $\left(0.00808 \mathrm{~g} \mathrm{seed}^{-1}\right)$, and although seeds can be held in closed var. clausa cones for a number of years, germination rates decline from $93 \%$ for fresh seed to $<49 \%$ for seed $>1$-year-old (Barnett \& McLemore, 1965). Individual longevity tends to be greater in var. immuginata (Parker et al., 2001); this variety is more resistant to several species of root rot (Outcalt \& Balmer, 1983). Despite the maintenance by each variety of a high proportion of the allozyme variation evident at the species level, Parker \& Hamrick (1996) found intervarietal differences in allele frequencies and greater mean 


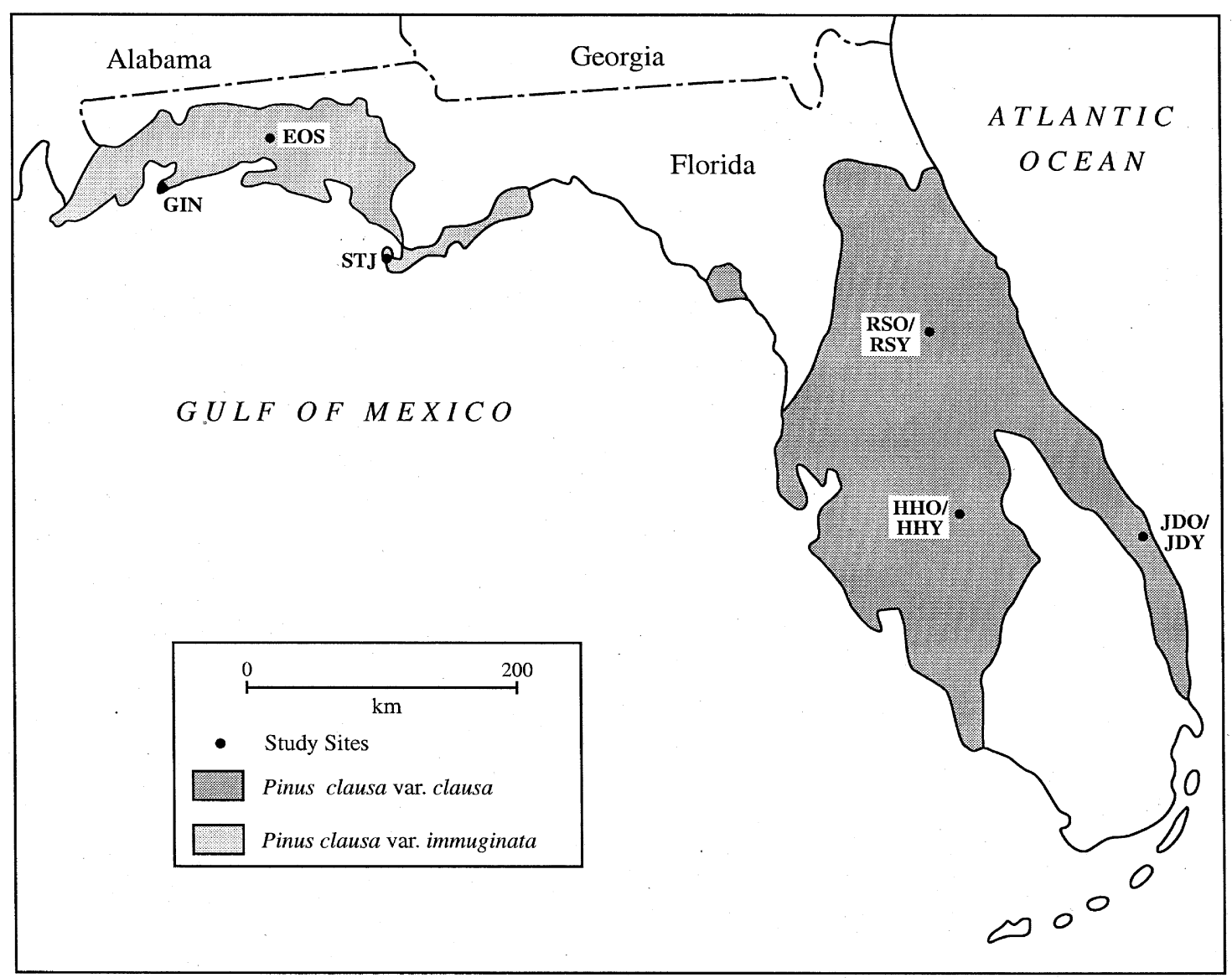

Fig. 1 Ranges of Pinus clausa var. clausa and var. immuginata and the locations of the nine populations sampled for allozyme analyses.

genetic distances between populations of different varieties than of the same variety.

\section{Field procedures}

From a range-wide analysis of genetic variation within and among 21 Pinus clausa populations (Parker \& Hamrick, 1996; Parker et al., 1997b), three sites for each variety were selected to examine spatial genetic structure within populations (Fig. 1). Sites for var. immuginata were located in the Florida panhandle and included an inland forest occupying Quaternary dunes in the eastern part of Eglin Air Force Base (EOS), a near-coastal forest in the Naval Live Oak section of Gulf Island National Seashore (GIN), and an open, stunted woodland along the coast at St. Joseph Peninsula State Park (STJ; Table 1). Because all the var. clausa sites examined had partially burned within the last 40 years, we sampled two populations in each site: one in the mature, unburned part of the site, and one in the more recently burned area that included numerous seedlings and saplings. Var. clausa sites in the Florida peninsula included two inland forests on the Lake Wales Ridge, at Rock Springs Run State Reserve and Highlands Hammock State Park, and a near-coastal forest at Jonathan Dickinson State Park. The younger populations at each site, designated RSY, HHY, and JDY, were included to examine the effects of relatively recent disturbance on genetic structure. The matched older populations, designated RSO, HHO, and JDO, were included to compare genetic structure in mature forests of the two varieties, as well as in different-aged populations of the same variety. At each var. clausa site, matched young and old plots were separated by at least $0.25 \mathrm{~km}$ and their genetic structure was examined separately. Populations were sampled with one plot each, which ranged from $40 \times 40$ to $60 \times 60 \mathrm{~m}(0.16-0.36 \mathrm{ha})$, with size adjusted to include a minimum of 100 mature individuals or, where present, $\approx 200-300$ seedlings and saplings (Table 1). All plots were randomly located in homogeneous areas dominated by a $P$. clausa overstorey. Areas with obvious microhabitat heterogeneity were avoided to minimize the possible effect of selection on genetic structure. 
Table 1 Location and characteristics of the Pinus clausa populations sampled

\begin{tabular}{|c|c|c|c|c|c|c|}
\hline $\begin{array}{l}\text { Sub- } \\
\text { population }\end{array}$ & Location & Lat. & Long. & $\begin{array}{c}\text { Plot } \\
\text { size (ha) }\end{array}$ & $\begin{array}{l}\text { Age of oldest } \\
\text { individual }(\mathrm{yr})^{*}\end{array}$ & Population/disturbance history \\
\hline \multicolumn{7}{|c|}{ Pinus clausa var. immuginata } \\
\hline EOS & $\begin{array}{l}\text { Eglin Air Force Base, } \\
\text { Scrub Hill }\end{array}$ & $30^{\circ} 34^{\prime} \mathrm{N}$ & $86^{\circ} 09^{\prime} \mathrm{W}$ & 0.25 & 118 & $\begin{array}{l}\text { Continuous } P \text {. clausa dominance, } \\
\text { occasional hurricane damage }\end{array}$ \\
\hline GIN & $\begin{array}{l}\text { Gulf Islands National } \\
\text { Seashore, Naval Live } \\
\text { Oaks Section }\end{array}$ & $30^{\circ} 22^{\prime} \mathrm{N}$ & $87^{\circ} 08^{\prime} \mathrm{W}$ & 0.16 & 70 & $\begin{array}{l}\text { Former } P \text {. palustris forest, invaded } \\
\text { by } P \text {. clausa with land use } \\
\text { change and fire suppression } \dagger\end{array}$ \\
\hline STJ & $\begin{array}{l}\text { St. Joseph Peninsula } \\
\text { State Park }\end{array}$ & $29^{\circ} 48^{\prime} \mathrm{N}$ & $85^{\circ} 25^{\prime} \mathrm{W}$ & 0.16 & 132 & $\begin{array}{l}\text { Continuous P. clausa dominance, } \\
\text { frequent hurricane damage }\end{array}$ \\
\hline \multicolumn{7}{|c|}{ Pinus clausa var. clausa } \\
\hline RSY & $\begin{array}{l}\text { Rock Springs Run } \\
\text { State Reserve, } \\
\text { recently disturbed }\end{array}$ & $28^{\circ} 46^{\prime} \mathrm{N}$ & $81^{\circ} 27^{\prime} \mathrm{W}$ & 0.25 & 25 & $\begin{array}{l}\text { Regeneration following fire in early } \\
\text { 1970s; no survivors from fire }\end{array}$ \\
\hline RSO & $\begin{array}{l}\text { Rock Springs Run } \\
\text { State Reserve, } \\
\text { mature forest }\end{array}$ & $28^{\circ} 46^{\prime} \mathrm{N}$ & $81^{\circ} 27^{\prime} \mathrm{W}$ & 0.16 & 60 & $\begin{array}{l}\text { Stand initiated in mid 1930s } \\
\text { following fire }\end{array}$ \\
\hline HHY & $\begin{array}{l}\text { Highlands Hammock } \\
\text { State Park, } \\
\text { recently disturbed }\end{array}$ & $27^{\circ} 29^{\prime} \mathrm{N}$ & $81^{\circ} 31^{\prime} \mathrm{W}$ & 0.16 & 39 & $\begin{array}{l}\text { Stand initiated following fire in } \\
\text { 1956; no survivors from fire }\end{array}$ \\
\hline $\mathrm{HHO}$ & $\begin{array}{l}\text { Highlands Hammock } \\
\text { State Park, } \\
\text { mature forest }\end{array}$ & $27^{\circ} 29^{\prime} \mathrm{N}$ & $81^{\circ} 31^{\prime} \mathrm{W}$ & 0.25 & 59 & $\begin{array}{l}\text { Stand initiated in early } 1930 \text { s } \\
\text { following fire }\end{array}$ \\
\hline JDY & $\begin{array}{l}\text { Jonathan Dickinson } \\
\text { State Park, } \\
\text { recently disturbed }\end{array}$ & $27^{\circ} 02^{\prime} \mathrm{N}$ & $80^{\circ} 07^{\prime} \mathrm{W}$ & 0.25 & 45 & $\begin{array}{l}\text { Regeneration following fire in } \\
\text { 1971; part of stand survived fire }\end{array}$ \\
\hline JDO & $\begin{array}{l}\text { Jonathan Dickinson } \\
\text { State Park, } \\
\text { mature forest }\end{array}$ & $27^{\circ} 01^{\prime} \mathrm{N}$ & $80^{\circ} 07^{\prime} \mathrm{W}$ & 0.36 & 71 & $\begin{array}{l}\text { Stand initiated in mid } 1920 \mathrm{~s} \\
\text { following fire or agricultural } \\
\text { abandonment }\end{array}$ \\
\hline
\end{tabular}

*Parker et al. (2001); †McCay (2000).

A tacheometric survey was made with a theodolite in each plot to map a lattice of $80-120$ individuals; remaining individuals were infilled from those survey points with a compass and tape measure (planimetric accuracy, $\pm 0.2 \mathrm{~m}$ over $25 \mathrm{~m}$, or $\approx 0.8 \%$ ). Mapped individuals comprised all living Pinus clausa seedlings [ $<2 \mathrm{~cm}$ diameter at breast height (d.b.h., $1.4 \mathrm{~m}$ above ground)], saplings (from $2 \mathrm{~cm}$ to $10 \mathrm{~cm}$ d.b.h.), and trees ( $>10 \mathrm{~cm}$ d.b.h.) within the plot. The d.b.h. of all mapped saplings and trees was recorded; seedling heights were recorded by $0.5 \mathrm{~m}$-increment height classes. Needles and terminal buds were collected from each individual in each population, placed on ice immediately, returned to the University of Georgia within four days, and stored at $5^{\circ} \mathrm{C}$ until protein extraction.

\section{Electrophoresis}

Needles and buds from each sample were crushed to a powder in liquid nitrogen. The powder was mixed with a potassium phosphate extraction buffer (Mitton et al.,
1979), and the extract was adsorbed onto filter paper wicks and stored at $-70^{\circ} \mathrm{C}$ for $3-4$ months until needed for electrophoresis.

Starch gel electrophoresis was used to determine allozyme variation within populations. Allozyme loci that Parker \& Hamrick (1996) found to be polymorphic (i.e. frequency of the most common allele $\leq 0.99$ ) in at least two of the populations they examined were selected for analysis of within-population genetic structure. Four buffer systems and eight enzyme stains resolved 12 loci on $10 \%$ Sigma starch gels: triose-phosphate isomerase (Tpil, Tpi2) and diaphorase (Dial) were resolved with buffer system 34/40; D-asparate aminotransferase (Aat1, Aat2) was resolved with buffer system 7; fluorescent esterase $(\mathrm{Fe} 1, \mathrm{Fe} 2)$ was resolved with buffer system 8; and shikimate 5-dehydrogenase $(S k d h), 6$-phosphogluconic-dehydrogenase (6Pgd1, 6Pgd2), phosphoglucoisomerase (Pgi2), and malate dehydrogenase ( $M d h)$ were resolved with buffer system 11 (Sherman-Broyles et al., 1992). Additional details of the electrophoretic protocol are provided by Parker \& Hamrick (1996). 


\section{Data analysis}

Three standard measures of genetic diversity were calculated for each population: percentage of polymorphic loci $(P)$, mean number of alleles per locus $(A)$, and the expected heterozygosity $\left(H_{\mathrm{e}}\right)$ (Hamrick et al., 1979). Wright's (1965) fixation index $\left(F_{\mathrm{IS}}\right)$, averaged over all loci, was used to assess the overall departure from Hardy-Weinberg equilibrium for each population; 95\% confidence levels were determined by multiplying the standard error by 1.96 to test whether $F_{\text {IS }}$ values were significantly different from zero (Loiselle et al., 1995). Fixation indices were also used to estimate deviations from Hardy-Weinberg expectations for each polymorphic locus in each population (Wright, 1965); values were tested for significance with chi-squared analysis (Li \& Horvitz, 1953).

In populations with sufficient juveniles (seedlings) and adults (saplings and trees; EOS, GIN, STJ, RSY, and JDY), allele frequencies and $F_{\text {IS }}$ values were calculated for each size class and tested for significant differences between size classes with chi-squared analysis (Workman \& Niswander, 1970). Although the distinction between juveniles and adults in this context is based on size, it corresponds reasonably well with reproductive maturity. Based on seedling growth rates (Parker et al., 2001), saplings have typically reached reproductive maturity, whereas seedlings are generally not reproductively active because they are $<5$-year-old (the minimum reproductive age in Pinus clausa; Cooper et al., 1959), or they are suppressed ecologically. For each population where both juveniles and adults were sufficiently abundant, $G_{\text {ST }}$ values (Nei, 1973) were calculated as a measure of the amount of genetic differentiation between the two size classes. $G_{\mathrm{ST}}$ values were also calculated for each matched pair of var. clausa populations to determine how much differentiation was evident between mature and adjacent, more recently regenerated populations.

Spatial genetic structure within populations was assessed with estimates of coancestry (Cockerham, 1969) between all possible pairs of individuals at different interplant distances. In order to estimate coancestry, genotypes for individuals were first expressed as allele frequencies of $1.0,0.5$, or 0.0 , depending on whether their genotype comprised 2, 1, or 0 copies of that allele (Heywood, 1991). Estimates of coancestry $\left(\rho_{i j}\right)$ were calculated as:

$\hat{\rho}_{i j}=\frac{\sum_{i j}\left(p_{i} \bar{p}\right)\left(p_{j} \quad \bar{p}\right)}{k \bar{p}(1 \quad \bar{p})}+\frac{2}{(8 k+1)^{0.5} \quad 1} \quad(i<j)$

where $p_{i}$ and $p_{j}$ are the frequencies of homologous alleles at a locus for individuals $i$ and $j ; p$ is the mean frequency for that allele; and $k=n(n-1) / 2$, which gives the number of possible pairs between $n$ individuals located in each distance class (Loiselle et al., 1995). The second term in the equation adjusts for bias associated with a finite sample size; this causes the estimate of coancestry to be zero for a population in Hardy-Weinberg equilibrium. The correlation between pairs of plants in their frequencies of homologous alleles at a given locus $\left(\rho_{i j}\right)$ in an outbreeding population $\left(F_{\text {IS }}=0\right)$ has expected values of 0.125 and 0.0625 for half-sibs and first cousins, respectively. A combined multilocus estimate of coancestry can be obtained by weighting the values for each locus by its polymorphic index, $\sum p_{i}\left(1-p_{i}\right)$. In this study, weightings were also adjusted for differences in sample size among loci because of missing genotypes (Loiselle et al., 1995). Multilocus coancestry estimates provide a more powerful measure of genetic structure than spatial autocorrelation analysis based on join-counts, which treats individual genotypes nomimally as classes and uses join-count statistics to assess the spatial pattern (Heywood, 1991). Population-wide multilocus estimates of coancestry were calculated at 5-m interplant-distance increments for each plot, as well as separate estimates for adult and juvenile layers where both size classes were present. In multisize-class populations with sufficient trees, coancestry was also estimated for the tree layer alone.

Estimates of coancestry were tested for significance with a randomization procedure that generated populations with a random spatial distribution of genotypes (i.e. no spatial structure). In each plot, intact multilocus genotypes were randomly drawn, with replacement, from the sampled data and assigned to points occupied by plants; new $\rho_{i j}$ values were then calculated. This randomization procedure was repeated 399 times for each plot, giving (together with the originally sampled data) $400 \rho_{i j}$ values, from which $95 \%$ and $99 \%$ intervals were constructed. The procedure tests the significance of the correlation in multilocus genotypes at each distance interval (Slatkin \& Arter, 1991). Programs for conducting autocorrelation analyses of coancestry are available from J. D. Nason upon request.

\section{Results}

\section{Genetic diversity}

Seven of the 12 loci scored were polymorphic in all nine populations. The three coastal populations (STJ, JDY, and JDO) had higher percentages of polymorphic loci $(P)$ than all inland populations, regardless of variety (Table 2). The inland peninsula sites (var. clausa) had the lowest $P$-values. The mean number of alleles per 


\begin{tabular}{|c|c|c|c|c|c|}
\hline Population & $N$ & $P$ & $A(\mathrm{SE})$ & $H_{\mathrm{o}}(\mathrm{SE})$ & $H_{\mathrm{e}}(\mathrm{SE})$ \\
\hline \multicolumn{6}{|c|}{ Pinus clausa var. immuginata } \\
\hline EOS & 179 & 81.8 & $2.18(0.22)$ & $0.131(0.051)$ & $0.130(0.048)$ \\
\hline GIN & 748 & 83.3 & $2.33(0.22)$ & $0.090(0.034)$ & $0.091(0.035)$ \\
\hline STJ & 304 & 91.7 & $2.33(0.19)$ & $0.127(0.038)$ & $0.134(0.042)$ \\
\hline \multicolumn{6}{|c|}{ Pinus clausa var. clausa } \\
\hline RSY & 221 & 75.0 & $2.08(0.23)$ & $0.151(0.046)$ & $0.144(0.044)$ \\
\hline RSO & 90 & 75.0 & $2.17(0.24)$ & $0.104(0.040)$ & $0.102(0.040)$ \\
\hline HHY & 127 & 63.6 & $2.00(0.29)$ & $0.135(0.053)$ & $0.149(0.060)$ \\
\hline $\mathrm{HHO}$ & 103 & 66.7 & $2.08(0.31)$ & $0.102(0.045)$ & $0.117(0.053)$ \\
\hline JDY & 231 & 91.7 & $2.42(0.26)$ & $0.133(0.050)$ & $0.143(0.054)$ \\
\hline JDO & 104 & 90.9 & $2.18(0.17)$ & $0.191(0.064)$ & $0.180(0.059)$ \\
\hline
\end{tabular}

Table 2 Summary of allozyme variation $^{1}$ for 12 loci within nine populations of Pinus clausa

${ }^{1} N$, number of $P$. clausa individuals sampled; $P$, percentage polymorphic loci; $A$, mean number of alleles per locus; $H_{\mathrm{o}}$, observed heterozygosity; and $H_{\mathrm{e}}$, heterozygosity expected under Hardy-Weinberg equilibrium.

locus was greater than two in all populations; Tpi and Dia both had four alleles in at least one population. The three young var. clausa populations had greater expected heterozygosities $\left(H_{\mathrm{e}}\right)$ than all var. immuginata populations; JDO, the old coastal var. clausa population, had the highest genetic diversity of all nine populations.

\section{Levels of inbreeding}

Inbreeding coefficients $\left(F_{\text {IS }}\right)$ across all loci for individual populations were generally close to zero, particularly for var. immuginata. Overall $F_{\mathrm{IS}}$ values for populations ranged from -0.001 to 0.009 for var. immuginata and from -0.030 to 0.034 for var. clausa (Table 3 ). RSO was the only population with an $F_{\text {IS }}$ value that differed significantly from zero.

The $F_{\text {IS }}$ values calculated for individual size classes showed little evidence of consistent changes in levels of inbreeding with increased size, as has been reported by others (e.g. Epperson, 1992; Table 3). As was the case for overall populations, $F_{\text {IS }}$ values were small. The adult layer in RSY was the only size class whose $F_{\text {IS }}$ value differed significantly from zero; the negative value for this size class indicates a heterozygote excess.

Genotype frequencies conformed to Hardy-Weinberg expectations for most loci in most populations. Eight of the 84 chi-squared tests $(9.5 \%)$ for polymorphic loci in separate populations indicated a significant departure from Hardy-Weinberg equilibrium, which is slightly above the number expected by chance (at $P<0.05$ ). Positive significant $F_{\text {IS }}$ values for individual loci were three times as numerous as negative values, indicating that a deficiency of heterozygotes was more frequent than an excess.

The more detailed analysis of inbreeding coefficients for individual loci by size class revealed that juveniles and
Table 3 Fixation indices $\left(F_{\text {IS }}\right)$ for each population and size-class ${ }^{1}$

\begin{tabular}{lrl}
\hline Subpopulation & \multicolumn{1}{c}{$F_{\text {IS }}$} & SE \\
\hline Pinus clausa var. immuginata & & \\
EOS & 0.003 & 0.026 \\
$\quad$ juveniles & -0.008 & 0.025 \\
adults & 0.006 & 0.030 \\
GIN & -0.001 & 0.010 \\
$\quad$ juveniles & -0.003 & 0.010 \\
$\quad$ adults & 0.008 & 0.021 \\
STJ & 0.009 & 0.017 \\
$\quad$ juveniles & -0.001 & 0.026 \\
adults & 0.016 & 0.018 \\
Pinus clausa var. clausa & & \\
JDY & 0.034 & 0.020 \\
$\quad$ juveniles & 0.049 & 0.037 \\
adults & 0.014 & 0.022 \\
JDO & -0.029 & 0.024 \\
RSY & -0.030 & 0.016 \\
juveniles & -0.028 & 0.019 \\
adults & $-0.038^{*}$ & 0.012 \\
RSO & $-0.022^{*}$ & 0.009 \\
HHY & 0.017 & 0.019 \\
HHO & 0.028 & 0.028 \\
\hline
\end{tabular}

${ }^{1}$ Only populations with a sufficient number of both adults (trees and saplings) and juveniles (seedlings) were included in the size-class analysis.

${ }^{*} P<0.05$

adults accounted for similar percentages of the significant deviations from Hardy-Weinberg expectations. Nine of the 95 chi-squared tests $(9.5 \%)$ of polymorphic loci in populations with two size groups (EOS, GIN, STJ, RSY, and JDY) showed significant departures from HardyWeinberg expectations; these involved six different loci. 

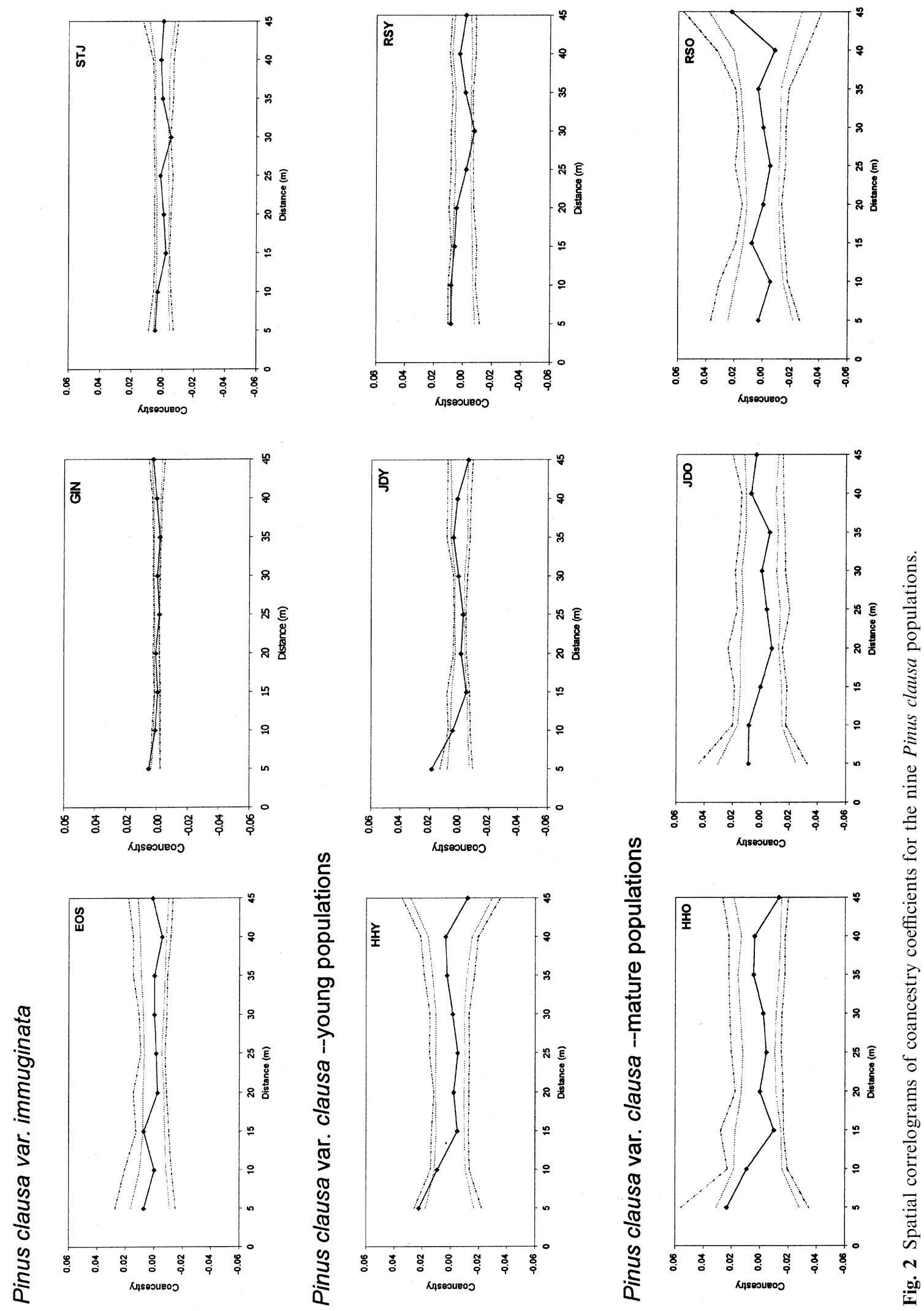

(C) The Genetics Society of Great Britain, Heredity, 87, 99-113. 
Seven of the nine significant deviations indicated a heterozygote deficit. Patterns were not consistent for the various loci; e.g. Aat 2 had a significant heterozygote deficit in STJ but an excess in EOS.

Genetic differentiation between juvenile and adult size classes in individual populations was low (all $G_{\mathrm{ST}}$ values $\leq 0.003$ ). The $G_{\mathrm{ST}}$ values between young and old sites for the three var. clausa population pairs were slightly larger; values ranged from 0.003 for JDY-JDO and HHY-HHO to 0.008 for RSY-RSO.

\section{Fine-scale genetic structure}

Evidence of spatial genetic structure differed among the nine Pinus clausa populations. All three young var. clausa populations (RSY, HHY, and JDY) had significant multilocus coancestry coefficients at interplant distances of either 5 or $10 \mathrm{~m}$ (Fig. 2). In contrast, the spatial distribution of genotypes in the three mature populations of var. clausa (RSO, HHO, and JDO) failed to depart from random at any interplant distance. Of the var. immuginata populations, only GIN exhibited significant genetic structure at close interplant distances; however, with a coancestry coefficient of $<0.006$ at $5 \mathrm{~m}$, this structure was weak. Because of the large sample sizes in many populations, the coancestry analysis had substantial power to detect the significance of even relatively small deviations from $\rho_{i j}=0$. Genetic structure was not evident in either STJ or EOS. Some significant coancestry coefficients for individual loci were evident in each population, but patterns were not consistent among distance classes or populations for those loci. Multilocus coancestry coefficients at interplant distances beyond $10 \mathrm{~m}$ were generally not significantly different from zero, except in three isolated cases. In GIN, STJ, and RSY, significant negative coancestry values were seen at some interplant distances between 25 and $35 \mathrm{~m}$, but adjacent distance classes were characterized by a random distribution of genotypes (Fig. 2). Such a pattern may have resulted from the chance location of two genetically dissimilar clusters of plants at that interplant distance (Loiselle et al., 1995).

Although most populations with a positive spatial autocorrelation of closely spaced genotypes also had an aggregated distribution of individuals (Fig. 3; maps are shown only for representative populations), the relationship between the spatial distribution of individuals and genotypes was complex (Table 4). Populations GIN, RSY, and JDY were characterized by aggregated distributions of both plants and genotypes, a reflection of the abundance of seedling patches that included related individuals (Fig. 3). In fact, in these three populations, only juveniles exhibited genetic structure; genotypes were distributed randomly among adults in these populations (Fig. 4). In contrast, HHY had a random arrangement of plants (nearly $90 \%$ of which were trees) but a significant positive autocorrelation of genotypes; it was the only population in which trees were significantly related at close interplant distances. Population HHY experienced a fire within the last 40 years, but the near-absence of seedlings and saplings made it unique among the younger var. clausa populations. Both STJ and EOS had aggregated plant distributions but no evidence of genetic structure. Many seedling patches in these two populations included plants large enough to be trees (Fig. 3); indeed, the tree layers in these two populations were significantly aggregated, in addition to the seedling-sapling layers (Parker et al., 2001). Dense patches in these two populations, which included a diversity of sizes and ages (Parker et al., 2001), did not show the same degree of interrelatedness that was evident within patches in GIN. Older var. clausa populations (RSO, HHO, and JDO) had a random distribution of both individuals and genotypes (Fig. 3).

The relationship between population density and genetic structure in these nine populations was similarly complex. Overall densities were generally greater in populations with well-developed seedling layers (Fig. 5); and among these, GIN and STJ (both var. immuginata) were the two densest populations. Four of the five densest populations were also characterized by a positive autocorrelation of genotypes; the exception was STJ with a random distribution of genotypes. Among the var. immuginata populations, GIN supported both the greatest overall and seedling densities, and it was the only population characterized by significant genetic structure. In var. clausa, only the younger populations showed genetic structure; these generally had lower adult densities but much higher juvenile densities than their mature counterparts (except HHY). These varied results reflect the different ways population density can influence the development of genetic structure.

\section{Discussion}

Where genetic structure was evident in the nine Pinus clausa populations, it was only weakly developed at the shortest interplant distances. Coancestry coefficients were low relative to expected values for clusters of half-sibs and first cousins, indicating that even in populations with significant spatial genetic structure, most individuals were not closely related. Most other studies of wind-pollinated and wind-dispersed plant species have similarly found little evidence of finer-scale genetic structure within populations (e.g. Boyle et al., 1990; Knowles, 1991; Perry \& Knowles, 1991; Knowles et al., 1992; Leonardi et al., 1996). Epperson \& Allard 

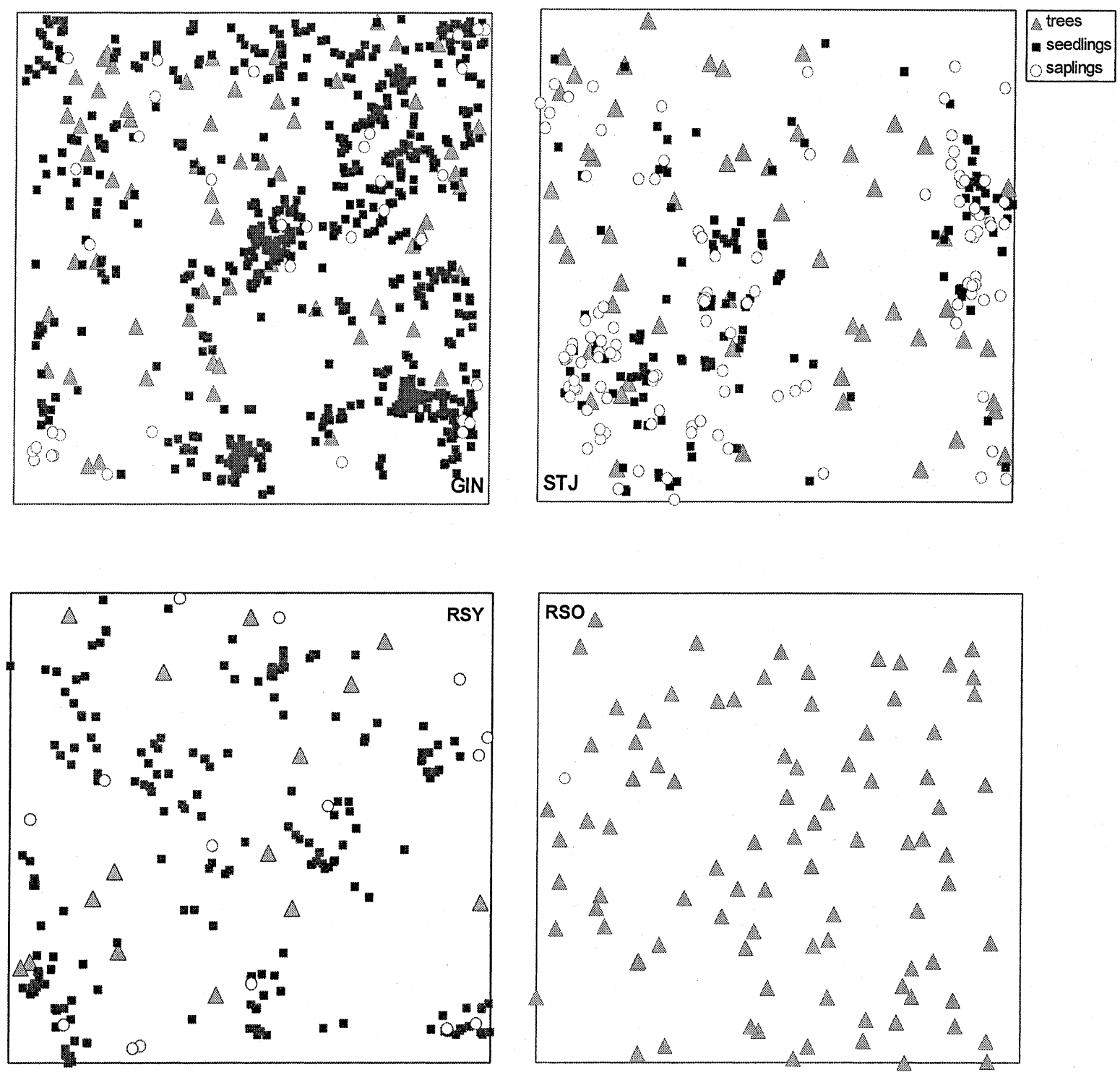

Fig. 3 Maps of Pinus clausa individuals by size class for GIN, STJ, RSY, and RSO, shown at a scale of 1:725 for RSY and 1:580 for the other populations.

(1989) attributed the absence of large patches of related individuals in $P$. contorta to high levels of gene flow effected by the dispersal of both pollen and seed over relatively long distances. $P$. clausa seeds likely disperse over relatively long distances as well; its winged seeds are intermediate in weight between those of $P$. contorta and Psuedotsuga menziesii (U. S. Forest Service, 1948), which are both species characterized by relatively longdistance seed movement (Epperson \& Allard, 1989). Particularly when the scale of analysis is small relative to gene dispersal, as is the case in this study, the longdistance dispersal of seeds and pollen is generally sufficient to prevent isolation by distance and associated genetic structuring (McCauley et al., 1996).
The small $F_{\mathrm{IS}}$ values for $P$. clausa indicated that populations were not characterized by appreciable inbreeding. Only one of the nine populations had a significant departure from Hardy-Weinberg equilibrium, and it had an excess of heterozygotes rather than a deficit. Other outcrossed conifer species often show a decrease in the frequency of homozygotes from the embryo stage through the sapling stage to adulthood, as homozygotes are selected against (Knowles, 1991; Mitton et al., 1997; Ledig, 1998). Consistent size-class related changes in the fixation index were not evident in $P$. clausa, which suggests that pollen dispersal has been over a sufficiently broad area to limit inbreeding or that selection against inbred plants has already reduced 
Table 4 Spatial distribution of Pinus clausa individuals and associated allozyme variation

\begin{tabular}{|c|c|c|}
\hline Population & $\begin{array}{l}\text { Departure from } \\
\text { random stem } \\
\text { distribution, } 0-10 \mathrm{~m}^{1}\end{array}$ & $\begin{array}{l}\text { Departure from } \\
\text { random distribution } \\
\text { of allozyme } \\
\text { variation, } 0-10 \mathrm{~m}\end{array}$ \\
\hline \multicolumn{3}{|c|}{ Pinus clausa var. immuginata } \\
\hline EOS & + & 0 \\
\hline GIN & + & + \\
\hline STJ & + & 0 \\
\hline \multicolumn{3}{|c|}{ Pinus clausa var. clausa } \\
\hline RSY & + & + \\
\hline RSO & 0 & 0 \\
\hline HHY & 0 & + \\
\hline $\mathrm{HHO}$ & 0 & 0 \\
\hline JDY & + & + \\
\hline JDO & 0 & 0 \\
\hline
\end{tabular}

${ }^{1}$ as indicated by second-order neighbourhood analysis (Ripley, 1977) of all living P. clausa individuals (Parker et al., 2001)); + indicates significant positive departure from random at an interplant distance of either 5 or $10 \mathrm{~m}$; 0 indicates a random distribution at both 5 and $10 \mathrm{~m}$.

homozygote excesses in the seedling and sapling layers of most populations. In many pine species, germination rates are lower for inbred seed than for outcrossed seed (Ledig, 1998); and in serotinous species, inbred progeny often have lower survivorship than outcrossed seeds within closed cones (Cheliak et al., 1985; Snyder et al., 1985). Others have reported a relatively rapid selective attrition of homozygote excesses in predominantly outcrossed species that were initially caused by inbreeding (e.g. Leonardi et al., 1996).

In $P$. clausa populations where genetic structure was evident, the clumping of genotypes most likely resulted from limited seed dispersal from the mother plant. Even though winged seeds of most conifers can disperse relatively long distances, studies have shown that the seed distribution pattern is typically leptokurtic around the mother plant, leading to a clumping of relatives in the vicinity of the parent (Hamrick \& Nason, 1996; Latta et al., 1998). Loiselle et al. (1995) similarly attributed the fine-scale genetic structure they observed in the animalpollinated and -dispersed tropical shrub Psychotria officinalis to dispersal of seeds near the mother plant, rather than to limited pollen movement. Although there was some aggregation of related individuals in certain Pinus clausa populations, the low coancestry coefficients overall relative to expected values for siblings indicated extensive overlap of seed shadows in most of the populations analysed (cf. Young \& Merriam, 1994) for Acer saccharum). In support of this conclusion is the observation that for the low-density, wind-pollinated tropical tree Platy- podium elegans, $\rho_{i j}$ values are much higher and the scale of significant coancestry is much broader than for Pinus clausa, indicating that there is little overlap of seed shadows for that species (Hamrick et al., 1993; Hamrick \& Nason, 1996).

Genetic structure was not developed uniformly in the nine $P$. clausa populations. While a number of studies have reported either a random distribution of genotypes or weak genetic structure at highly localized scales within populations of temperate plant species, $P$. clausa joins a growing list of species that exhibit variation among populations in the development of fine-scale spatial genetic structure (e.g. P. banksiana: Xie \& Knowles, 1991; Larix laricina: Knowles et al., 1992; Picea mariana: Boyle et al., 1990; Acer saccharum: Young \& Merriam, 1994; Fagus sylvatica: Leonardi \& Menozzi, 1996). Authors who have compared two or three populations have often attributed contrasts in genetic structure to specific causes, such as stand history or homogeneity of seed sources. In comparisons of a larger number of populations (e.g. Leonardi \& Menozzi, 1996), however, identification of factors fostering spatial variation in genetic structuring has been more difficult, most likely because of the diverse array of influences on fine-scale genetic structure and their complex variation throughout a species' range.

In the case of $P$. clausa, localized genetic structure was primarily evident in populations with an abundance of seedlings and saplings. Furthermore, clumping of genotypes in these populations with both juveniles and adults was restricted to the juvenile layer; no population with genetic structure among seedlings and saplings also had genetic structure among adults. Population HHY was somewhat different from all other populations in two respects. It was the only recently disturbed population that comprised relatively young tree-sized individuals but very few smaller individuals, and it was also the only population with genetic structure within the tree layer. Together the $P$. clausa populations suggest the following scenario: genetic structure arises in many populations because limited seed dispersal results in patches of related seedlings in the vicinity of mother plants. There is subsequent attrition of this genetic structure, as only one or two individuals per seedling patch survive competitive thinning to reach adulthood (Hamrick et al., 1993). HHY appears to be in a transitional phase of this trajectory; it has thinned sufficiently that the spatial distribution of stems is no longer aggregated (Parker et al., 2001), but genotypes still show significant clumping. The disappearance of genetic structure from younger to older cohorts with competitive thinning has been reported in other species, including Quercus laevis (Berg \& Hamrick, 1995), Alseis 
Pinus clausa var. immuginata

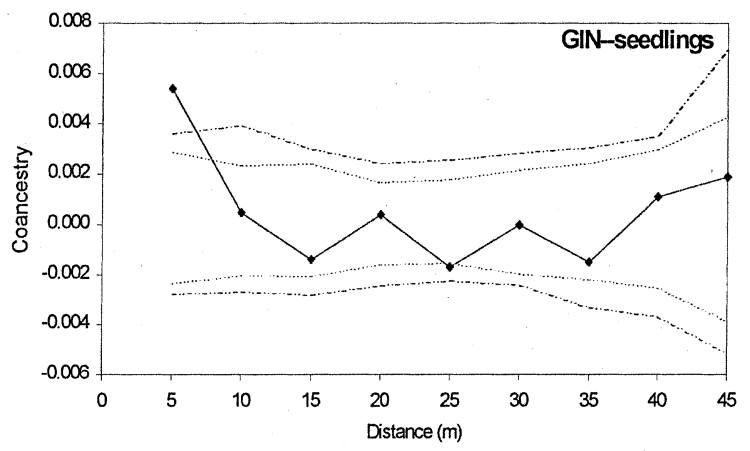

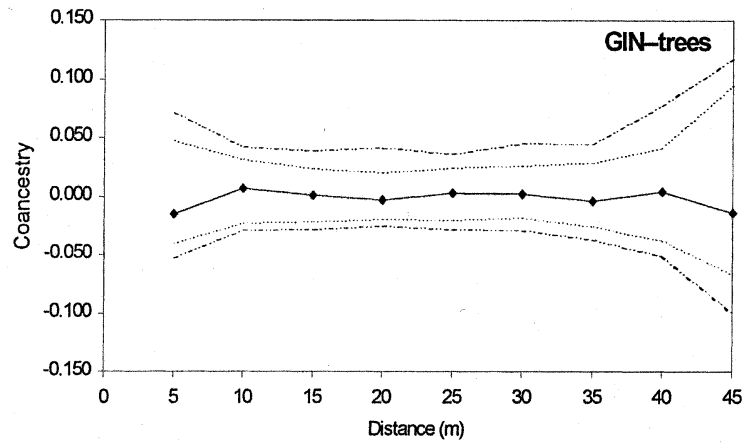

Pinus clausa var. clausa --young populations
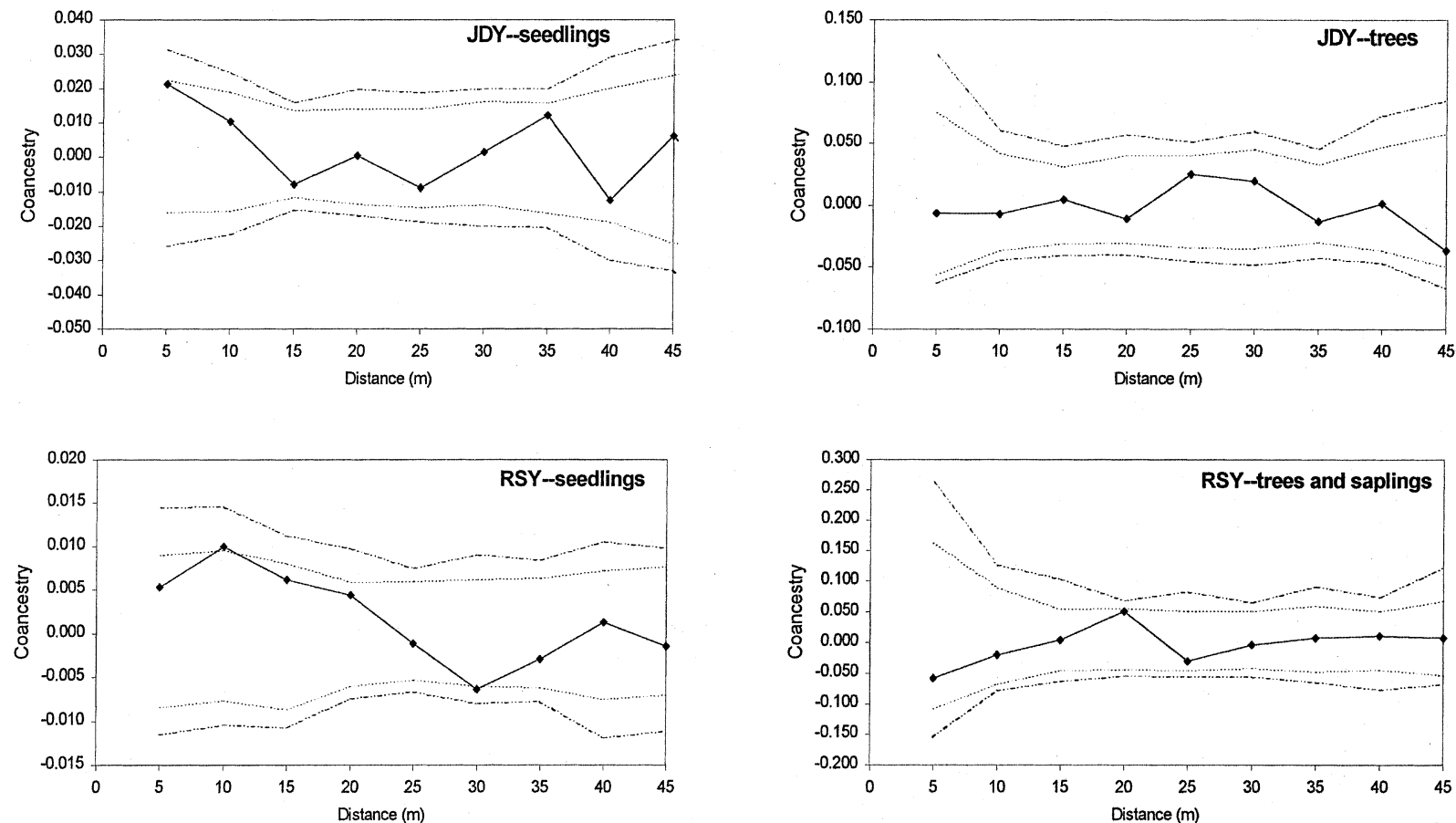

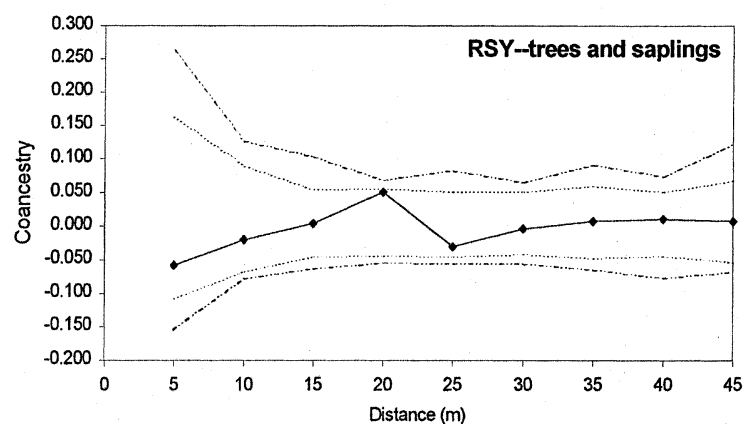

Fig. 4 Coancestry coefficients calculated separately for seedlings and either trees (in GIN and JDY) or trees and saplings combined (RSY; these two classes were combined because of the low number of both saplings and trees in this population).

blackiana, Platypodium elegans (Hamrick et al., 1993), and Cecropia obtusifolia (Epperson \& Alvarez-Buyella, 1997). This pattern indicates that genetic structure caused by limited seed dispersal is often relatively ephemeral when not reinforced by similarly localized pollen dispersal or by differential selection among microhabitats (Hamrick \& Nason, 1996).

The effect of density on the development of genetic structure in $P$. clausa is complex and differs somewhat between varieties, in part because of demographic differences that reflect disturbance history. Theoretically, density can shape genetic structure in a population in several ways. First, adult density influences the distribution of genotypes in younger cohorts because the arrangement of adults, along with environmental controls, dictates patterns of pollen flow and seed dispersal. Denser adults tend to have overlapping seed shadows to a greater degree, which limits the development of genetic structure as seeds from those trees germinate and become established (Hamrick et al., 1993; Young \& Merriam, 1994; Hamrick \& Nason, 1996). For P. clausa, modern adult density is an important potential control of genetic structure primarily in var. immuginata, where regeneration is continuous. The three var. immuginata populations examined were not sufficiently different in adult density, however, for

(C) The Genetics Society of Great Britain, Heredity, 87, 99-113. 

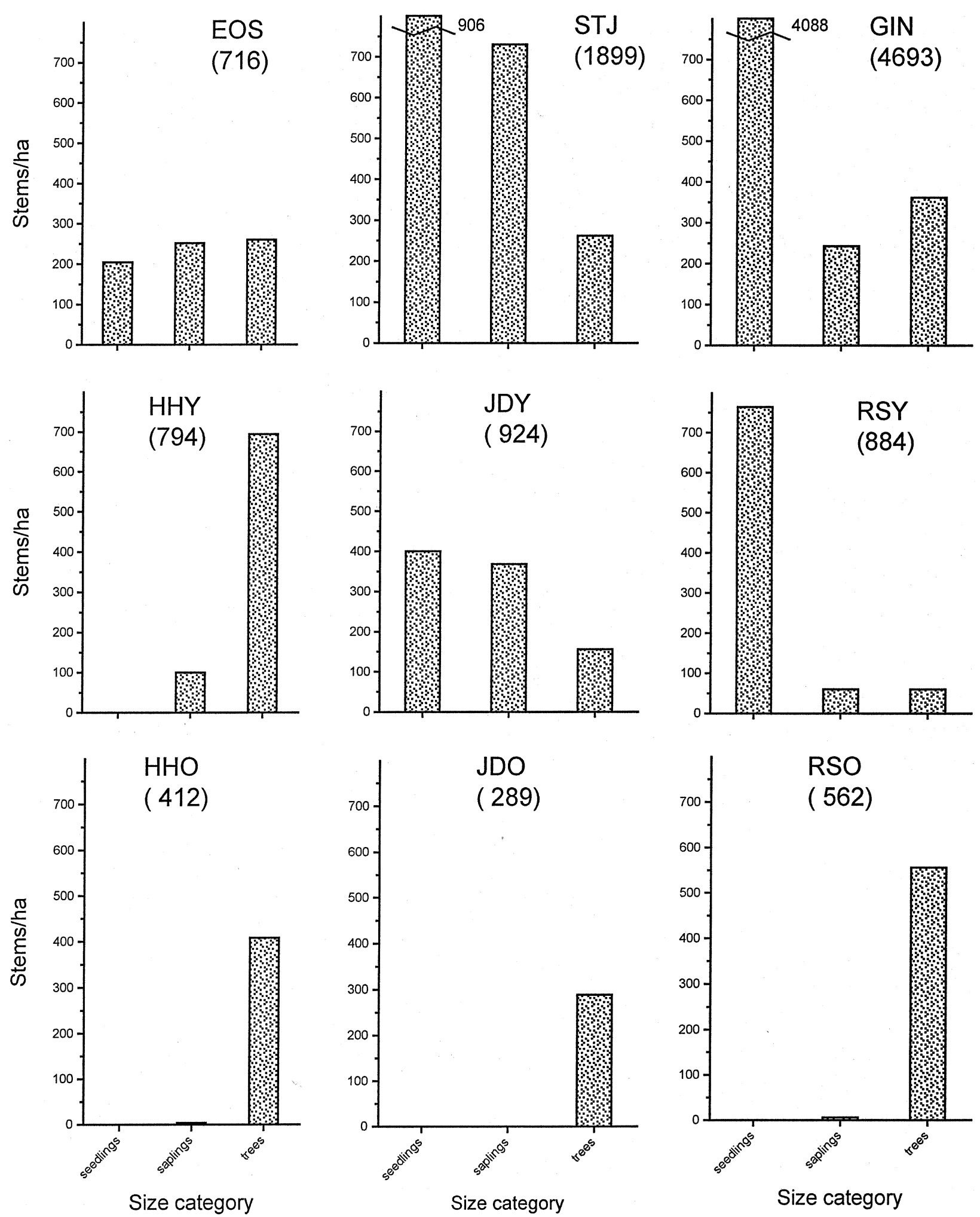

Fig. 5 Size-class structures of the nine Pinus clausa populations; numbers indicated parenthetically are total population densities in stems/ha. 
this influence to be evident. In mature var. clausa populations, where regeneration only occurs after standdestroying disturbance, genetic structure is a legacy of the initial seed dispersal pattern after disturbance, modified by subsequent seedling survival, rather than a function of modern adult density.

Second, the density of young plants may affect the development of genetic structure in a very different way from the effect of adult density: populations with a greater density of seedlings may exhibit aggregated genotypes if seed dispersal is limited to the immediate vicinity of mother plants (Loiselle et al., 1995; Latta et al., 1998). Such genetic structure often disappears as cohorts age and competitive thinning occurs (Berg \& Hamrick, 1995; Epperson \& Alvarez-Buylla, 1997). In $P$. clausa, the effect of seedling density on genetic structure was similar for both varieties. Populations characterized by clumps of seedlings of a similar age had aggregated genotypes (GIN, RSY, and JDY). In contrast, two populations had patches that comprised a greater variety of both sizes and ages (STJ and EOS), and the distribution of genotypes was random in these populations. The absence of clumped genotypes in STJ and EOS may reflect appreciable interannual variation in seed and seedling allele frequencies, as has been reported in both Pinus contorta (Hamrick \& Nason, 1996) and P. banksiana (Cheliak et al., 1985), which would offset the effect of limited seed dispersal on the development of genetic structure.

Third, when a population results from colonization of a site after a canopy fire or other intense disturbance, the density of nearby seed trees can affect genetic structure (Knowles et al., 1992). Fires that triggered regeneration in each of the three younger var. clausa populations left surviving trees in close proximity to the burned area. These, along with the release of seeds from burned trees, potentially supplied abundant seeds for recolonization of those sites. The weak structure among juveniles caused by aggregation of related seedlings, and the absence of structure among adults in young var. clausa populations is in keeping with previous studies that reported little evidence of genetic structure where recolonization from a homogeneous seed source followed a relatively small disturbance (Boyle et al., 1990; Knowles et al., 1992). Boyle et al. (1990) noted, however, that characteristics of individual fires and postfire climatic conditions may complicate generalizations about seed tree density and the development of genetic structure.

\section{Conclusions}

Our results indicate that the development and maintenance of genetic structure in Pinus clausa populations are more complex than originally hypothesized. Contrary to our initial expectations, continuous gap-phase replacement has not fostered long-term genetic structure in var. immuginata populations. Genetic structure was observed in one of the three immuginata populations examined, but only amongst seedlings and saplings. Structure was not apparent among trees, probably because individuals in this layer were sole survivors from patches of related seedlings that had undergone competitive thinning. Other controls on gene flow, such as geographical variation in recruitment ecology, tend to complicate the effect of gap-phase regeneration on genetic structure in var. immuginata.

The development of fine-scale genetic structure is undoubtedly complex in var. clausa also, although the populations examined reveal a more consistent pattern. The older populations supported our original hypothesis of an absence of genetic structure in these populations that presumably regenerated from a relatively homogeneous seed source. Recruitment from disparate seed sources after disturbance may foster the development of genetic differentiation at a slightly broader scale, but the plot size used in this study was too small to detect such influences. In contrast, genetic structure was evident in all the young var. clausa populations examined. Regeneration in this variety often results in dense patches of similarly aged, related seedlings. Such structure apparently deteriorates by the time survivors of competitive thinning in seedling patches reach adulthood; therefore, the genetic structure created through limited seed dispersal in the vicinity of the mother plant is a shortlived phenomenon in var. clausa populations.

\section{Acknowledgements}

The authors thank Elizabeth Stacy and Mindy EdwardsBurke for lab assistance; Deanna McCay, Juliana Evans, Matthew Beaty, and David Conway for field assistance; Mike Feeney of Cartographic Service at the University of Georgia for drafting the site map; Dana Bryan, Dick Roberts, and Parks Small of the Florida Department of Environmental Protection, Scott Hassell, Rick McWhite, Carl Petrick, and Steve Seiber of Jackson Guard, Eglin Air Force Base, and Riley Hoggard of the National Park Service for logistical support during field work. This research was supported by NSF grant SBR-9313704 and an associated REU Supplement SBR-9443100 to KCP and AJP.

\section{References}

BARnetT, J. P. AND Mclemore, B. F. 1965. Cone and Seed Characteristics of Sand Pine. U.S. Forest Service Research Paper SO-19. Southern Forest Experiment Station, New Orleans, LA. 
BERG, E. E. AND HAMRICK, J. L. 1995. Fine-scale genetic structure of a turkey oak forest. Evolution, 49, 110-120.

BOYLE, T., LIENGSIRI, C. AND PIEWLUANG, C. 1990. Genetic structure of black spruce on two contrasting sites. Heredity, 65, 393-399.

CHELIAK, W. M., DANCIK, B. P., MORGAN, K., YEH, F. C. H. AND STROBECK, C. 1985. Temporal variation of the mating system in a natural population of jack pine. Genetics, 109, 569-584. COCKERHAM, C. C. 1969. Variance of gene frequencies. Evolution, 23, 72-84.

COOPER, R. W., SCHOPMEYER, C. S. AND McGREGOR, W. H. D. 1959. Sand Pine Regeneration on the Ocala National Forest. Production Research Report 30. United States Department of Agriculture, Forest Service, Washington, D.C.

ELlSTRAND, N. C. 1992. Gene flow among seed plant populations. New Forests, 6, 241-256.

EPPERSON, B. K. 1992. Spatial structure of genetic variation within populations of forest trees. New Forests, 6, 257-278.

EPPERSON, B. K. AND ALLARD, R. W. 1989. Spatial autocorrelation analysis of the distribution of genotypes within populations of lodgepole pine. Genetics, 121, 369-377.

EPPERSON, B. K. AND ALVAREZ-BUYLLA, E. R. 1997. Limited seed dispersal and genetic structure in life stages of Cecropia obtusifolia. Evolution, 51, 275-282.

HAMRICK, J. L. AND NASON, J. D. 1996. Consequences of dispersal in plants. In: Rhodes, O. E., Chesser, R. K. and Smith, M. H. (eds) Population Dynamics in Ecological Space and Time, pp. 203-236. University of Chicago Press, Chicago, IL.

HAMRICK, J. L., LINHART, Y. B. AND MITTON, J. B. 1979. Relationships between life history characteristics and electrophoretically detectable genetic variation in plants. Ann. Rev. Ecol. Syst., 10, 173-200.

HAMriCK, J. L., MURAWSKI, D. A. AND NASON, J. D. 1993. The influence of seed dispersal mechanisms on the genetic structure of tropical tree populations. Vegetatio, 107/108, 281-297.

HEYWOOD, J. S. 1991. Spatial analysis of genetic variation in plant populations. Ann. Rev. Ecol. Syst., 22, 335-355.

KNOWLES, P. 1991. Spatial genetic structure within two natural stands of black spruce (Picea mariana (Mill.) B.S.P.). Silvae Genet., 40, 13-19.

KNOWleS, P., PERRY, D. J. AND FOSTER, H. A. 1992. Spatial genetic structure in two tamarack [Larix laricina (Du Roi) K. Kock] populations with differing establishment histories. Evolution, 46, 572-576.

LATTA, R. G., LiNhART, Y. B., FLECK, D. AND Elliot, M. 1998. Direct and indirect estimates of seed versus pollen movement within a population of ponderosa pine. Evolution, 52, 61-67.

LEDIG, F. T. 1998. Genetic variation in Pinus. In: Richardson, D. M. (ed.) Ecology and Biogeography of Pinus, pp. 251-280. Cambridge University Press, Cambridge.

LEONARDI, S. AND MENOZZI, P. 1996. Spatial structure of genetic variability in natural stands of Fagus sylvatica $\mathrm{L}$. (beech) in Italy. Heredity, 77, 359-368.

LEONARDI, S., RADDI, S. AND BORGHETTI, M. 1996. Spatial autocorrelation of allozyme traits in a Norway spruce (Picea abies) population. Can. J. For. Res., 26, 63-71.
LI, C. C. AND HORVITZ, D. G. 1953. Some methods of estimating the inbreeding coefficient. Am. J. Hum. Genet., 5, 107-117.

LiNHART, Y. B., MITTON, J. B., STURGEON, K. B. AND DAVIS, M. L. 1981. Genetic variation in space and time in a population of ponderosa pine. Heredity, 46, 407-426.

LitTle, E. L. Jr. AND DORMAN, K. W. 1952. Geographic differences in cone-opening in sand pine. J. Forestry, 50, 204-205.

LOISElle, B. A., SORK, V. L., NASON, J. AND GRAHAM, C. 1995. Spatial genetic structure of a tropical understory shrub Psychotria officinalis (Rubiaceae). Am. J. Bot., 82, 14201425.

MCCAULEY, D. E. 1997. The relative contributions of seed and pollen movement to the local genetic structure of Silene alba. J. Hered., 88, 257-263.

McCAUleY, D. E., STEVENS, J. E., PERONI, P. A. AND RAVEILl, J. A. 1996. The spatial distribution of chloroplast DNA and allozyme polymorphisms within a population of Silene alba (Caryophyllaceae). Am. J. Bot., 83, 727-731.

McCAY, D. H. 2000. The effects of chronic human activities on invasion of longleaf pine forests by sand pine. Ecosystems, $\mathbf{3}$, 283-292.

MITTON, J. B., LINHART, Y. B., STURGEON, K. B. AND HAMRICK, J. L. 1979. Allozyme polymorphisms detected in mature needle tissue of ponderosa pine. J. Hered., 70, 86-89.

MitTON, J. B., LATTA, R. G. AND REHFELDT, G. E. 1997. The pattern of inbreeding in Washoe pine and survival of inbred progeny under optimal environmental conditions. Silvae Genet., 46, 215-219.

MYERS, R. L. 1990. Scrub and high pine. In: Myers, R. L. and Ewel, J. J. (eds) Ecosystems of Florida, pp. 150-193. University of Central Florida Press, Orlando, FL.

NEI, M. 1973. Analysis of gene diversity in subdivided populations. Proc. Natl. Acad. Sci. U.S.A., 70, 3321-3323.

OutcAlt, K. W. AND BALMER, w. E. 1983. Sand pine. In: Silvicultural Systems for the Major Forest Types of the Unites States, U. S. Forest Service Agricultural Handbook 445, pp. 170-171. United States Department of Agriculture, Washington, D.C.

PARKER, K. C. AND HAMRICK, J. L. 1996. Genetic variation in sand pine (Pinus clausa). Can. J. For. Res., 26, 244-254.

PARKer, A. J., PARKer, K. C. AND McCAY, D. H. 2001. Disturbance-mediated variation in stand structure between varieties of Pinus clausa (sand pine). Ann. Ass. Am. Geogr., 91, $28-47$.

PARKER, K. C., HAMrick, J. L., PARKER, A. J. AND STACY, E. A. 1997b. Allozyme diversity in Pinus virginiana (Pinaceae): Intraspecific and interspecific comparisons. Am. J. Bot., 84, 1372-1382.

PARKER, K. C., PARKER, A. J., BEATY, R. M., FULLER, M. M. AND FAUST, T. D. 1997a. Population structure and spatial pattern of two coastal populations of Ocala sand pine (Pinus clausa (Chapm. ex Engelm.) Vasey ex Sarg. var. clausa D. Ward). J. Torrey Bot. Soc., 124, 22-33.

PERRY, D. J. AND KNOWLES, P. 1991. Spatial genetic structure within three sugar maple (Acer saccharum Marsh.) stands. Heredity, 66, 137-142.

RIPLEY, B. D. 1977. Modelling spatial patterns. J. R. Statist. Soc. B, 39, 172-192. 
SCHNABEL, A. AND HAMRICK, J. L. 1995. Understanding the population genetic structure of Gleditsia triacanthos L. The scale and pattern of pollen gene flow. Evolution, 49, 921-931.

SCHNABEL, A., NASON, J. D. AND HAMRICK, J. L. 1998. Understanding the population structure of Gleditsia triacanthos L. Seed dispersal and variation in female reproductive success. Mol. Ecol., 7, 819-832.

SHERMAN-BROYLES, S. L., GIBSON, J. P., HAMRICK, J. L., BUCHER, M. A. AND GIBSON, M. J. 1992. Comparisons of allozyme diversity among rare and widespread Rhus species. Syst. Bot., 17, 551-559.

SLATKIN, M. AND ARTER, H. E. 1991. Spatial autocorrelation methods in population genetics. Am. Nat., 138, 499-517.

SNYDER, T. P., STEWART, D. A. AND STRICKLER, A. F. 1985. Temporal analysis of breeding structure in jack pine (Pinus banksiana Lamb.). Can. J. For. Res., 15, 1159-1166.
U. S. FOREST SERVICE. 1948. Woody-plant Seed Manual. Miscellaneous Publication 654. U. S. Government Printing Office. Washington, D. C.

WORKMAN, P. L. AND NISWANDER, J. D. 1970. Population studies on southwestern Indian tribes. II. Local genetic differentiation in the Papago. Am. J. Hum. Genet., 22, 24-49.

WRIGHT, S. 1943. Isolation by distance. Genetics, 28, 114-138. WRIGHT, S. 1965. The interpretation of population structure by F-statistics with special regard to systems of mating. Evolution, 19, 395-420.

XIE, C. Y. AND KNOWLES, P. 1991. Spatial genetic substructure within natural populations of jack pine (Pinus banksiana). Can. J. Bot., 69, 547-551.

YOUNG, A. G. AND MERRIAM, H. G. 1994. Effects of forest fragmentation on the spatial genetic structure of Acer saccharum Marsh. (sugar maple) populations. Heredity, $\mathbf{7 2}$, 201-208. 